Egypt. Acad. J. Biolog. Sci., 12(2):71-77(2020)

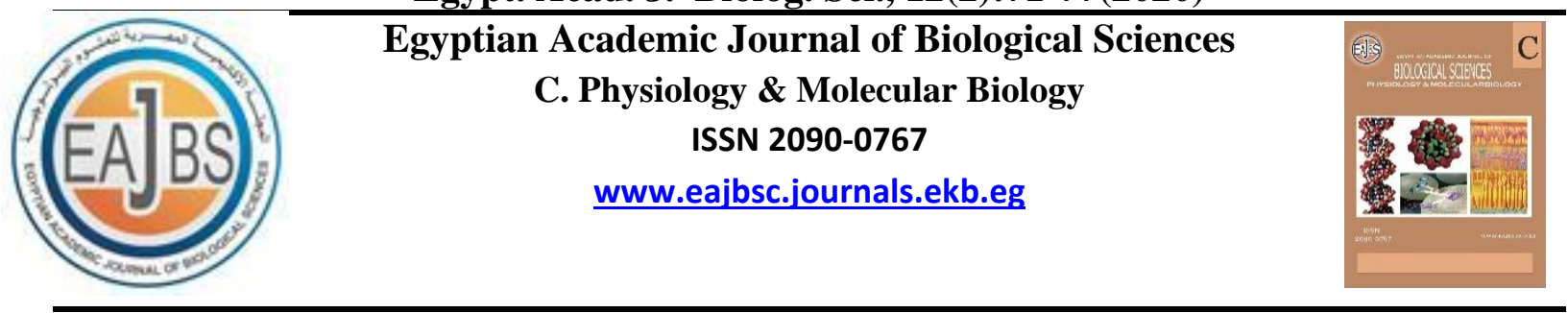

\title{
Evaluation of the Heavy Metals Pb, Cd, and Fe in Muscles, Liver, and Skin of Mugil cephalus (Mugilidae) from Tubrukharbor, Eastern Libya
}

\author{
Yousef K. A. Abdalhafid ${ }^{1}$,Salma M. Aboubakr ${ }^{2}$, Mousa M.Y.Kateesh ${ }^{1}$ and \\ Sayed M. Ali ${ }^{1}$ \\ 1-Faculty Science, Omar Al-Mukhtar University, Al Bayda, Libya \\ 2-Faculty Science.OMar Al-Mukhtar University. Al-Qubba \\ E.Mail:salma1981sa@Gmail.com
}

\begin{tabular}{ll}
\hline $\begin{array}{l}\text { ARTICLE INFO } \\
\text { Article History } \\
\text { Received:20/6/2020 } \\
\text { Accepted:30/8/2020 }\end{array}$ & $\begin{array}{l}\text { ABSTRACT } \\
\text { Heavy metal concentrations Lead Pb, Cadmium Cd, and Iron Fe) were } \\
\text { Tobrukharbor, eastern Libya. The results revealed that the concentration of Pb } \\
\text { reached high levels in the skin, while recorded low levels in the liver tissues. Pb } \\
\text { level in the liver, skin, and muscle tissues of Mugil cephalus was more than the } \\
\text { Keywords: }\end{array}$ \\
$\begin{array}{l}\text { Ppollution- } \\
\text { Mugilcephalus - } \\
\text { heavymetals - }\end{array}$ & $\begin{array}{l}\text { while, recorded its low concentration in the skin. Also, maximum levels of Cd } \\
\text { were detected in the liver, while it attained their low level in the muscles. } \\
\text { libya. }\end{array}$ \\
$\begin{array}{l}\text { Generally, the level of Pb and Fe in muscle tissues of } \text { Mugil cephalus was more } \\
\text { than the international standard and the level of Cd in muscle tissue of } \text { Mugil } \\
\text { cephalus was lower than the general standard. On the other hand, heavy metals } \\
\text { concentration levels in seawaterofTobrukharbor, eastern Libya, exhibited a high } \\
\text { level for Fe then Pb comparing to the level of Cd. The relationship between size } \\
\text { and weight of Mugil cephalus and the levels of each metal was studied. }\end{array}$
\end{tabular}

\section{INTRODUCTION}

The effect of heavy metals pollution worldwide is considered one of the important problems in the last decades(Malik, et al.,2010). Human activities such as agriculture practices, industrialization, and an increase in population have further aggravated the situation (Giguereet al.,2004; Gupta,et al.,2009). Heavy metalsh ave the ability to bioaccumulate in aquatic ecosystems due to their potentially toxic effects(Miller, et al., 2002; Censi, et al., 2006). Some heavy metals such as copper and zinc are very important for metabolism, while $\mathrm{Pb}, \mathrm{Cd}$, and $\mathrm{Fe}$ have almost no role in living systems. On the other hand, they have dangerous effects on fish depending on their concentration. Coastal lagoons and harbor are considered a priority habitat, for exhibiting pollution by heavy metals, so, this study aims to the evaluation of lead, cadmium, and iron levels in the liver, muscles, and skin of Mugil cephalus (Mugilidae) from Tobrukharbor, eastern Libya.

\section{The Study Site:}

\section{MATERAILS AND METHODS}

Tobruk city lies on the coast of the East Mediterranean of the coast of Libya, extends from Bumba to the Egyptian border. The area of study extends along of Tubruk port eastern of Libya (long. $32^{\circ} 05^{\prime} \mathrm{N} 23^{\circ} 55^{\prime} \mathrm{E}$, Fig. 1). 


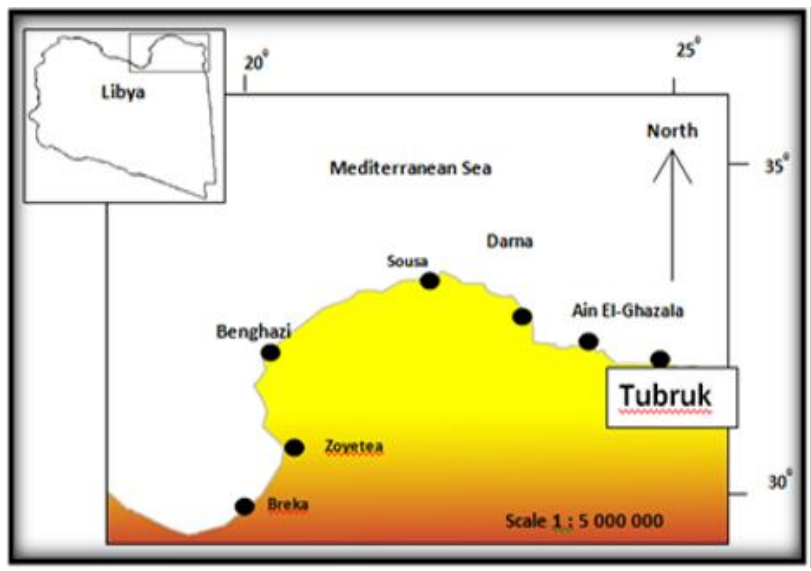

Fig.(1).Harbor of Tubruk

Fish Sampling:

Fifteen M. cephalus fish were collected from the Tubruk harbor between April to August 2016, then weight and length of fish were recorded to the nearest (millimeter/gram) and then all fish were dissected. To investigate the heavy metals variations in Mugil cephalus tissues, three different tissues were obtained from fish samples(liver, skin, and muscles).

Water sampling was done according to Salim (1987).
Tissue analysis and the procedure was carried out according to Pitor and Dragan (1996).

Water analysis and the procedure was achieved according to Salim (1987).

Statistical analysis was done with many tap differences with $p<0.05$ were considered significant.

\section{RESULTS}

\section{Length-Weight Relationship:}

The relationship between length and weight(millimeter/gram) are illustrated in figure 2.

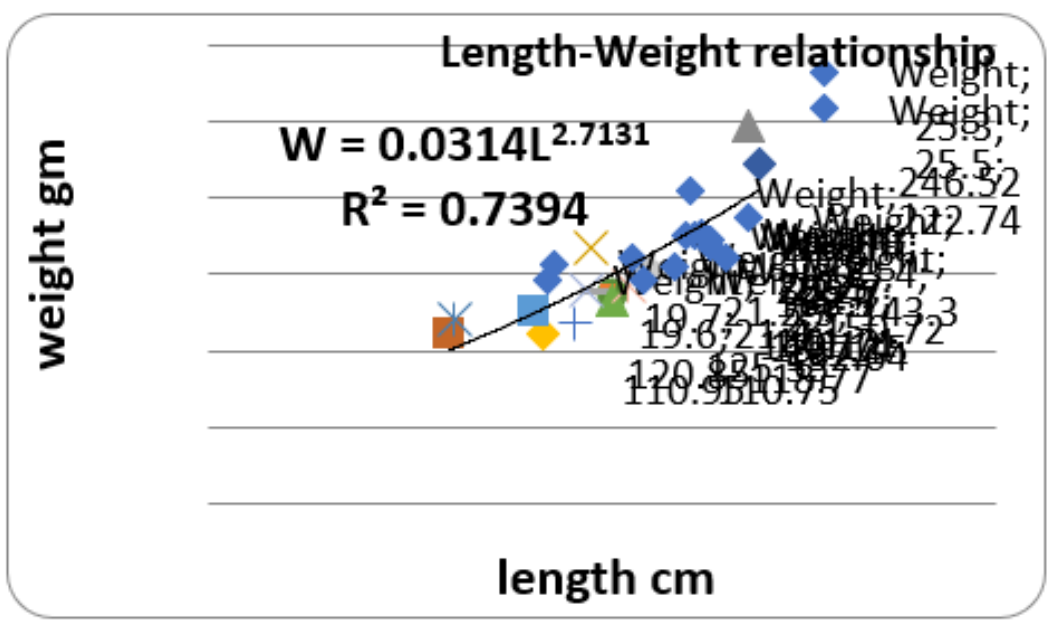

Fig.(2). Relationship between length and weight

$\mathrm{Pb}, \mathrm{Fe}$, and $\mathrm{Cd}$ in liver, skin, and muscle concentration levels, were tabulated (in ppm) in Table (1).

\section{The Concentration of $\mathbf{P b}$ (ppm):}

The obtained results cleared that the maximum concentration level of $\mathrm{Pb}$ was observed in the skin while the concentration in the liver was low in comparison with those in muscles.

Generally, the concentration of $\mathrm{Pb}$ in the muscle tissue of Mugil cephalus was more than the international standard.

The Concentration of $\mathrm{Fe}$ (ppm):

The maximum concentration of $\mathrm{Fe}$ was observed in liver tissue, while, the concentration in the skin was low in 
comparison with those in muscles. The concentration level of $\mathrm{Fe}$ in musculartissues of Mugil cephalus was more than the international standards.

\section{The Concentration of $\mathbf{C d}$ (ppm):}

The maximum level of $\mathrm{Cd}$ was observed in the liver tissue while the level in muscles was lower in comparison with those in the skin. The concentration level recorded for Cd in muscle tissue of Mugil cephalus was clearly lower compared with the international standard.

Table 1: The concentration of $\mathrm{Pb}, \mathrm{Fe}$, and $\mathrm{Cd}(\mathrm{ppm})($ mean $\pm \mathrm{SE})$ in liver, skin, and muscle tissues of Mugil cephalus in Tubruk, eastern Libya.

\begin{tabular}{|c|c|c|c|}
\hline Heavy metals & Liver & Skin & Muscles \\
\hline $\mathrm{Pb}$ & $0.386 .3 \pm 0.3$ & $0.8797 \pm 0.02$ & $0.6729 \pm 0.06$ \\
\hline $\mathbf{F e}$ & $312.82 \pm 5.0$ & $117.46 \pm 3.37$ & $236.14 \pm 12.37$ \\
\hline $\mathbf{C d}$ & $0.046 \pm 0.0045$ & $0.021 \pm 0.0011$ & $0.018 \pm 0.0005$ \\
\hline
\end{tabular}

Table (2) illustrates the coefficients of correlations between levels of $\mathrm{Pb}$ in liver, skin, and muscles with length and weight of Mugil cephalus, no correlations recorded between length and weight compared to the level of $\mathrm{Pb}$ in the skin, while there is astrong negative correlation between weight and the concentration of $\mathrm{Pb}$ in muscles and there was no correlation between length and the concentration of $\mathrm{Pb}$ in muscles. On the other hand, there is astrong positive correlation between weight and concentration of $\mathrm{Pb}$ in theliver comparing to length.

Table 2:Coefficients of correlations between levels of $\mathrm{Pb}$ in liver, skin, and muscles of M.cephalus versus fish length and weight.

\begin{tabular}{|c|c|c|c|}
\hline Tissue & Liver & Skin & Muscles \\
\hline Length & 0.221 & -0.199 & -0.161 \\
\hline Weight & 0.602 & -0.339 & -0.505 \\
\hline
\end{tabular}

Table (3) illustrates the coefficients of correlations between the concentration of $\mathrm{Fe}$ in liver, skin, and muscles compared to the length and weight of Mugil cephalus. There are no correlations between the concentration of Fe in liver, skin, and muscles compared to the length and compared to weight in the liver . while there is astrong negative correlation between levels of $\mathrm{Fe}$ and weight in skin and muscles.

Table 3:Coefficients of correlations between levels of $\mathrm{Fe}$ in liver, skin, and muscles of M.cephalus versus fish length and weight.

\begin{tabular}{|c|c|c|c|}
\hline Tissue & Liver & Skin & Muscles \\
\hline Length & -0.180 & -0.176 & -0.100 \\
\hline Weight & -0.033 & -0.555 & -0.527 \\
\hline
\end{tabular}

Coefficients of Correlations Relationship Between Levels of Cd in Liver, Skin, and Muscles of M.Cephalus Versus Fish Length and Weight:

Table (4) illustrates the coefficients of correlations between concentrations of $\mathrm{Cd}$ in liver, skin, and muscles compared to the length and weight of Mugil cephalus, there are no correlations between concentrations of $\mathrm{Cd}$ in the liver, skin, and muscles compared to length and weight. 
Table4: Coefficients of correlations between levels of Cd in liver, skin, and muscles of M.cephalusversus fish length and weight.

\begin{tabular}{|c|c|c|c|}
\hline Tissue & Liver & Skin & Muscles \\
\hline Length & 0.255 & 0.005 & 0.146 \\
\hline Weight & 0.115 & -0.303 & 0.082 \\
\hline
\end{tabular}

Table 5: Heavy metals: maximum permissible limit (MPL) in the fish muscle tissues $(\mu \mathrm{g} / \mathrm{g}$ wet wt) international standards.

\begin{tabular}{|c|c|c|c|c|}
\hline Metals & Pb & Fe & Cd & Reference \\
\hline The present study & $0.672 \pm 0.06$ & $236.14 \pm 12.37$ & $0.0182 \pm 0.0005$ & $\begin{array}{c}\text { The present } \\
\text { study }\end{array}$ \\
\hline FAO (1983) & 0.5 & & 0.05 & FAO (45) \\
\hline FAO/WHO Limit & 0.5 & & 0.5 & FAO/WHO (50) \\
\hline WHO1989 & 2 & 100 & 1 & Mokhtar (52) \\
\hline European & 0.2 & & 0.05 & EC (49) \\
\hline $\begin{array}{c}\text { Community } \\
\text { England }\end{array}$ & 2 & & 0.2 & MAFF (48) \\
\hline
\end{tabular}

Levels of the heavy metals $\mathrm{Pb}, \mathrm{Fe}$, and $\mathrm{Cd}$ (mean \pm standard error, ppm) in surface water of three sites within Tubruk harbor, eastern Libya, were presented in (Table 6).

Table 6: The concentration of the heavy metals $(\mathrm{Pb}, \mathrm{Fe}$, and $\mathrm{Cd})$ in the water of Tubruk harbor eastern Libya revealed the occurrence of ahigh concentration of Iron then Lead comparing to the concentration of Cadmium.

\begin{tabular}{|c|c|c|c|c|}
\hline Heavy metals & Site 1 & Site 2 & Site 3 & $\begin{array}{c}\text { Averages of } \\
\text { the sites }\end{array}$ \\
\hline $\mathrm{Pb}$ & $0.91 \pm 0.005$ & $1.02 \pm 0.008$ & $1.10 \pm 0.007$ & $1.011 \pm 0.005$ \\
\hline $\mathrm{Fe}$ & $244.8 \pm 0.59$ & $280.7 \pm 0.33$ & $331.7 \pm 0.28$ & $285.79 \pm 2.461$ \\
\hline $\mathrm{Cd}$ & $0.02 \pm 0.001$ & $0.03 \pm 0.0003$ & $0.01 \pm 0.0001$ & $0.028 \pm 0.0005$ \\
\hline
\end{tabular}

As shown in Table (7) heavy metals accumulation coefficient \% ( Indices of pollution) in liver, skin, and muscles of Mugil cephalus revealed higher levels of accumulation for $\mathrm{Cd}(164.28)$ and $\mathrm{Fe}$ (109.45) in the liver, then $\mathrm{Pb}(86.94)$ in skin and $\mathrm{Fe}$ (82.62) in muscles

Table7: Accumulation coefficient $\%$ of the studied heavy metals in the liver, skin, and muscles of M. cephalus.

\begin{tabular}{|c|c|c|c|}
\hline Heavy metals & Liver & Skin & Muscle \\
\hline $\mathrm{Pb}$ & 38.18 & 86.94 & 66.55 \\
\hline $\mathrm{Fe}$ & 109.45 & 41.10 & 82.62 \\
\hline $\mathrm{Cd}$ & 164.28 & 75 & 64.28 \\
\hline
\end{tabular}




\section{DISCUSSION}

According to the present results, the maximum level of $\mathrm{Pb}$ was showed in the skin, but, the concentration of $\mathrm{Pb}$ in liver tissue was lower in comparison with those in muscles, the level of $\mathrm{Pb}$ in liver, skin and muscle tissues of Mugil cephalus was more than the general international standard. While the maximum concentration of $\mathrm{Fe}$ was observed in the liver tissues, and the concentration level in the skin was lower in comparison with those in muscles. The level of $\mathrm{Fe}$ in muscle tissues of Mugil cephalus was more than the international standard. Furthermore, the maximum concentration level of $\mathrm{Cd}$ was observed in liver tissues while its level in the muscles was lower in comparison with those in the skin,. Generally, the concentration level of $\mathrm{Cd}$ in the muscle tissues of Mugil cephalus was clearly lower than the general international standard. Also, the relation between the size and weight of the examined fish and the concentration level of each heavy metal was determined. In general, in the muscles and liver, a linear relationship would best describe the data throughout the coefficient of correlation was not very high, and there was no significant correlation between the metal concentrations in the liver, skin, and muscles and the size of the individual fish.

The main sources of lead pollution in the seawater and ocean the shipping, movement of ships, and the oil tanker accidents. In the present research, the maximum concentration level of $\mathrm{Pb}$ was recorded in the skin, this result agrees with many authors who have reported that the skin and gill tissues are especially characterized by a mucus layer on their outer surfaceslikeY1lmaz,(Yilmaz,2005), who reported that. $\mathrm{Pb}$ levels reached high levels in the skin in Mugil cephalus, The occurrence of the mucus obviously affects the diffusion of water pollutants across the fish epidermis, serving as an effective barrier ( Yilmaz,2005).

Unlike to Safahieh, et al., (Safahieh, et al., 2011), Pb Concentration levels in muscle, liver, and gills in the Mullet fish, Liza abu from the Petrochemical Waste Receiving Creeks, Musa Estuary (Persian Gulf) were lower than the general standards. On the other hand, their study agreed with the attained results concerned with the concentration of Cd in muscle.

Similar findings were reported by Khidr and Dheina(2011), concerning heavy metal levels in thewater, fish, and plankton of Lake Manzala, Egypt, they found that the $\mathrm{Pb}$ concentration in the liver tissue was higher than the save limit particularly in the Gills but lower than the permissible limit in the muscle.

Muscles contained the lowest levels of the measured heavy metals. This result agreed with the findings of many researchers who have reported that fish muscles have a low tendency to accumulate the heavy metals which they are exposed (Blasco,et al., 1998; Canlt\&Kalay, 1998; khider\&Dheina, 2011; Kamaruzzaman, et al., 2011; Yilmaz, 2005 ).

$\mathrm{Cd}$ one of the important heavy metals is most common environmental pollutants and a dangerous threat due to its toxicity, biomagnification, and bioaccumulation in the food chain, Cd toxicity for humans appears its harmful effects on some organs such as kidney, bones, lung, brain and central nervous system (Castro-Gonzalez\&Mendez-Armenta, 2008).

Cd was the highest level in the liver. This result could be explained as the habitat of Mugilcephaluswhich live at the sea bottom, near to the sediment where different types of hazardous and toxic substances are accumulated (Ibrahim, et al., 1999).

Because the liver is a target organ for storage and detoxification of the excess of heavy metals uptake by fish, high concentrations of metals are accumulated in it. The liver is a good indicator of water pollution with heavy metals since their levels accumulated in liver tissues are often proportional to those that occur in the environment. That is especially true for iron, copper, and cadmium, levels in the liver tissues which rapidly increase during exposure, and remain high for long periods of depuration, when other organs are being cleared (Dang\&Wang, 2009). 
Trace metals contamination in sediment can affect water quality and the bioaccumulation of metals in marine organisms, causing potential long-term implications on human health as well as the ecosystem. With the rapid growth of population, increasing heavy metals loads in aquatic ecosystems as a result of human activities has become a major global concern.

The accumulation of heavy metals in liver tissues is likely a result of its role in body metabolism, high levels of $\mathrm{Cd}$ and $\mathrm{Fe}$ in liver tissues are usually linked to natural binding proteins such as metallothioneins (MT), which act as an essential metal store (Cd and $\mathrm{Fe})$ to fulfill enzymatic and other metabolic demands. In addition, iron tends to accumulate in the hepatic tissues due to the role of the liver in blood cells and hemoglobin synthesis. However, the liver also obtained high levels of non-essential metals such as cadmium; this could be explained by the ability of $\mathrm{Cd}$ to displace the normally MTassociated essential metals in hepatic tissues (Roesijadi, 1996, Amiard, et al., 2006; Qadir\&Malik, 2011).

\section{REFERENCES}

Amiard, J. C., Amiard-Triquet, C., Barka, S., Pellerin, J. and Rainbow, P. S. (2006) Metallothioneins in aquatic invertebrates: their role in metal detoxification and their use as biomarkers, Aquatic Toxicology,76:160-202.

Blasco, J., Rubio, J. A., Forja, J., Gomezparra, A. and Establier, R. (1998) Heavy metals in some fishes of the Muglilidae family from saltponds of Cadiz Bay, Spain. Ecotoxicology and Environmental Restoration, 1:71-77.

Canlt, M. and Atli, G. (2003) The relationships between heavy metal $(\mathrm{Cd}, \mathrm{Cr}, \mathrm{Cu}, \mathrm{Fe}, \mathrm{Pb}$, and $\mathrm{Zn})$ levels and the size of six Mediterranean fish species, Environmental Pollution, 121:129-136.

Canlt, M., Ay, And Kalay, M. (1998), Levels of heavy metals $(\mathrm{Cd}, \mathrm{Pb}, \mathrm{Cu}, \mathrm{Cr}$ and $\mathrm{Ni}$ ) in tissues of Cyprnuscarpio, Barbuscapito

and
Chondrostomaregium from the Seyhan River, Turkey, Turkish Journal of Zoology, 22:149-157.

Castro-González, M. I. and MéndezArmenta, M. (2008)Heavy metals: implications associated to fish consumption. Environmental Toxicology and Pharmacology, 26:263-271.

Censi, P., Spoto, S. E., Saiano, F., Sprovieri, M., Mazzola, S.andNardone, G., et al. (2006). Heavy metals in coastal water systems. A case study from the northwestern Gulf of Thailand. Chemosphere, 64, 1167-1176.

Dang and Wang (2009) Assessment of Tissue-Specific Accumulation and Effects of Cadmium in a Marine Fish Fed Contaminated Commercially Produced Diet, Aquatic Toxicology, Vol. 95, No. 3, Pp 248-255.

FAO(1992). Committee for Inland Fisheries of Africa, Report of the third session of the Working Party on pollution and fisheries, Accra, Ghana, 25-29 November 1991, FAO Fisheries Report,471, Rome, FAO

Giguere, A., Campbell, P. G. C., Hare, L, McDonald D. G. And Rasmussen, J. B. (2004). Influence of lake chemistry and fish age on cadmium, copper and zinc concentrations in various organs of indigenous yellow perch (Percaflavescens). Candian Journal of Fisheries and Aquatic Science, 61: 702-716.

Gorur, F. K., Keser, R., Akeay, N. and Dizman, S.,(2012) Radioactivity and heavy metal concentrations of some commercial fish species consumed in the Black Sea Region of Turkry. Chemosphere, 87:35-61.

Gupta, A., Rai, D. K., Pandey, R. S. And Sharma B (2009). Analysis of some heavy metals in the riverine water, sediments and fish from river Ganges at Allahabad. Environmental Monitoring and Assessment, 157: 449458.

Ibrahim,A. M., Bahnasawy, M. H., Mansy, S. 
E. and EL-Fayomy, R. I., (1999) Heavy metal accumulation in water, sediment and some fishes in Lake Manzala, Egypt. Journal of Egeptian Germeny Society of Zoology, 29:4358.

Kamaruzzaman, B. Y., Shuhada, N. T., Akbar, B., Shahbudin, S., Jalal, K. C. A., Ong, M. C., AL-Barwani, S. M. and Goddard, J. S.,(2011) Sptial Concentrations of Lead and Copper in bottom Sediments of Langkawi Coastal Area, Malaysia. Research Journal of Environmental Sciences, Volume 5 (2): 179-186,

Karadede, H., Oymak, S. A. and Ünlû, E.,(2004) Heavy metals in muliet, lizaabu, and catfish, Silurustriostegus, from the Atatûrk Dam Lake (Euphrates), Turkey. Environment International, 30:183-188.

Khider and Dheina (2011) Assessment of heavy metal concentrations in water, plankton, and fish of Lake Manzala. Egypt. Turkish Journal of Zoology, 35(2):271-280.

Malik N, Biswas AK, Qureshi TA, Borana K, Virha R (2010). Bioaccumulation of heavy metals in fish tissues of a freshwater lake of Bhopal. Environmental

Monitoring and Assessment, 160: $267-$ 267.

Miller, G. G., Sweet, L. I., Adams, J. V., Omann, G. M., Passino-Reader, D. \& Meter, P. G. (2002). In vitro toxicityand interactions of environmental contaminants (Arochlor 125 and mercury) and immunomodulatory agents (lipopolysaccharidae and cortisol) on thymocytes from lake trout
(Salvelinusnamaycus). Fish and Shell fish Immunology, 13, 11-26.

Pitor, C. H. and Dragan, P. Y. (1996) Chemical carcinogenesis. In: Casarett and Doull's Toxicology, $5^{\text {th }}$ ed., McGraw Hill, New York, Pp: 201260.

Qadir, A. and Malik, R. N. (2011) Heavy metal in eight edible fish species from two polluted tributaries (Aik and Palkhu) of the River Chenab. Pakistan. Biological trace element research, 143:1524-40.

Roesijadi, G. (1996) Metallothionein and its role in toxic metal regulation. Comparative Biochemistry \& Physiol ogy part C., 113(2):117-23.

Safahieh, A., Monikh, F., Savari, A. and Doraghi, A. (2011) Heavy Metals Concentration in Mullet Fish, Liza $a b u$ from Petrochemical Waste Receiving Creeks, Musa Estuary( Persian Gulf). Journal of Environmental Protection, 2, 12181226.

Salim, R. (1987) Effect of storge on the distribution of trace element $(\mathrm{Pd}, \mathrm{Cd}$, $\mathrm{Zn}$ and $\mathrm{Hg}$ ) in natural water, Journal of Environmental Science and health Part A: Environmental Science and Engineering, Vol. 22, NO. 1, Pp 5969.

WHO (World Health Organization) (1985) Guidelines for Drinking WaterQuality, $\quad$ Vol. 1.ReconmmendationWHO:Geneva, Pp:130.

Yilmaz, A. B.(2005) Comparison of heavy ( Sparusaurata) caught in Iskenderun Bay (Turkey). Turkish Journal of Veterinary and Animal Sciences, 29:257-262. 